\title{
The Origines of the University of Paris
}

YACERDOTIUM, Imperium, Studium, are brought together by a medieval writer ${ }^{1}$ as the three mysterious potencies or 'virtues' by whose harmonious co-operation the life and health of Christendom must be sustained. To the medieval mind the studium did not, any more then the sacerdotium or the imperium, represent a mere abstraction. As the secular hierarchy was crowned by the Holy Roman Empire, as the secerdotal order throughout Christendom looked for its head and centre to the city of the seven hills, so the intellectual life of medieval Errope found its concrete embodiment in an intellectual hierarchy, no less distinct and definite than the secular or the spiritual, whose head and centre was the nniversity of Paris. To the university of Paris, whose four facalties were likened by medieval imagination to the fourfold river of Paradise, conld be traced as to their ultimate source and fountain-head all the streams of knowledge by which the whole church was watered and fertilised. In the university of Paris-the 'first school of the church'-France possessed her equivalent to the Italian papacy and the German Casarship in the politico-ecclesisstical system of Enrope.

The development and organisation of an institution which held such a place in the conceptions of medieval Christendom is surely a subject of more than antiquarian interest. It demands the minute, elsborate, and serious investigation which has been abondantly bestowed apon the history of the papacy and empire. For the appreciation of the intellectual, social, and ecclesiastical life of the middle ages a knowledge of the university system is as important as a knowledge of the feudal system or of the ecclesiastical system, or of the constitutional history of particular states. Yet till the appearance of the work which we are about to notice very little had been done in the way of a serious and critical investigation of the subject, though as regards Paris and Oxford at least abundant materials had been collected. ${ }^{2}$ It is but yester-

1 'Jordanis Chronics,' quoted by Bryce, Holy Roman Empirs, 7th ed. p. 98, note.

2 In the masaive and laborious but stupid Historia Universitatis Parioiensis of Bulmas (6 vols. fol. Par. 1665), in the Histoire Litteraire do la France, and the Indez Chartarum portinentium ad Univervitatom Parioiensom of M. C. Jourdain 
day, indeed, that we emerged from the mythical period in the development of our subject. Such superstitions as the foundation of the university of Oxford by Alfred the Great or of the university of Paris by Charles the Great have been dispelled rather by the progress of a vague incredulity than by the diffusion of exacter knowledge. Even now these absurdities continue to be occasionally mentioned with a grave face. The Alfredian fable was accepted by Huber, whose worthless book is still appealed to as an authority; and it seems to have retained till a very recent period its hold upon the imagination of the fellows of the college, which still claims Alfred as its founder. ${ }^{1}$

General historians, though alive to the importance of the part which the universities played in medieval history, have usually dismissed the subject with a few rague and often misleading generalities. Milman, for instance ('Latin Christianity,' book xi. chap. 2), misled by the totally different constitution of Oxford, talks about the university of Paris maintaining her 'prerogative of sole and exclusive jurisdiction over her students,' a prerogative which was never claimed and never existed at Paris, least of all in the middle of the thirteenth century. The same historian makes Wyclif 'Warden of Baliol Hall on the presentation of Baliol College' (book xiii. 6) apparently because he had found the house over which Wyclif presided described as aula de Baliol, and did rot know that aula was a quite common designation of all the earliest colleges. Robertson, again, though (as usual) more accurate than Milman, fails to distinguish between the growth of schools in a particular place and the formation of a university in the proper sense of the word. Even Green's brilliant picture of medieval Oxford ${ }^{2}$ leaves upon the mind of the reader the totally erroneous impression that the teachers and students of the middle age were for the most part paupers, and that the ordinary lecture rooms were 'church-porch and house-porch.' These are a few samples, which might be extended indefinitely, of the kind of treatment which the historians have bestowed upon our subject. Other writers have avoided similar mistakes only by passing over in

(Рer. 1862, fol.), who prints in extenso the hitherto unpublished docaments. Antony 2. Wood's History of Oxford is an English classio, while Mr. Anstey's Mfunimenta Academica (Rolls Series, London, 1868) supplies the materials for oritical work. Mr. Anstey's preface is readable, though sometimes misleading, but the carelessness or ignorance exhibited by the marginal summaries is almost incredible, e.g. albi monachi is rendered ' white friars' (p. 78).

1 The college celebrated the millenary of its foundation in 1872. Its present master is still disposed to believe in the Altredian foundstion of schools at Oxford, whioh ought to have been dispelled by Heywood's oppendix to the English transla. tion of Huber's English Universitios (London, 1843). See Bright's History of England, p. 10. Mr. Parker's elsbarate exposare of the Oxford legend in his Early History of Oxford (1885) was not ancalled for.

2 Short Hist. of the English Pcople, ob. iii. 84 . London, 1874. 
absolute silence a series of events of such transcendent importance as the rise of the univergities.

If we turn to the special histories of particular universities, we find the best of them ${ }^{1}$ seriously marred by a want of familiarity with the history and organisation of other universities, especially of the archetypal or parent universities of Paris and Bologna. Of medieval Universitäts-Geschichte as a whole even a trustworthy sketch has hitherto been a desideratum. The only work worth mentioning was that of Meiners, which is generally admitted to be an unsatisfactory performance. ${ }^{2}$ Savigny ${ }^{3}$ contributed much to our knowledge of the Italian aniversities, but he knew little or nothing about Paris and Oxford. The first real book on the subject as a whole is likely to be, in a sense, the final one. As long ago as $1866 \mathrm{M}$. Renan in one of his essays ${ }^{4}$ noticed that the Dominican father, Heinrich Denifle, was engaged in preparing a book on "The Mendicant Orders and the University of Paris in the First Half of the Thirteenth Century.' The scope of the projected work has gradually expanded till it has assumed the form of a massive four-volume royal octavo on "The Universities of the Middle Ages to $1400 .^{5}$ Of the thoroughness, the patience, and the vast learning which have been brought to bear upon the task, it would be impossible to speak with sufficient admiration. When the work, of which the first volume is now before us, shall be complete, comparatively scanty gleanings will, in all probability, be left for future workers in the way of collecting fresh materials, and not very much in the way of better critical appreciation and interpretation of them. From a literary point of view no doubt much will remain to be desired. The book is certainly not one for the general reader, hardly even for the ordinary student of history. It is a book for the specia list. The plan of the father's work makes it difficult to estimate how far the want of breadth, of life, and of colour, which must be felt by every reader - at least every English reader - of the present volume, is destined to be supplied by its successors. The method of the author is severely 'analytical,' ${ }^{6}$ and the present volume deals almost entirely with the origines and early development of the universities which grew up or were founded up to 1400 A.D. The father leaves no question connected with his subject untouched. He will, therefore, no doubt come to the

\footnotetext{
1 Buch as Mr. Mallinger's in many respects admirable History of Cambridge. E.g. Mr. Mullinger makes Peter the Lambard archbishop of Paris in 1159.

Gesch. dor Entstehurg und Entwoickelung der hohen Schuten unseres IPrdthoils. 4 Thle. 8×0. Grttingen : 1802-5.

- Geschichto des romischon Rechts im Mittelalter.

- Nouvellas Etudes de l'Histoire Religiouse, ed. Paris 1884, p. 218.

- Die Universituten des Mittelalters bis 1400. Von P. Heinrich Denifle, ans dem Predigerorden, Unterarchivar des hl. Stahles. Berlin, 1886.

- See his apology, i., p. xriii.
} 
relations of the aniversities to the church and the European system at large, the social, religions, and intellectual life which went on in them, the part which they played in the development of modern civilisation, all in due time. Bat at present the work is a series of learned dissertations rather than a history. The book is invaluable to the professed student of university history, and may, it is hoped, clear the ground for the fature historian of Oxford when one of its two handred or so endowed researchers shall find leisure to write its history. But the reader who wishes to enjoy 'father Denifle's book must bring his interest in the subject with him; it will hardly be crested for him by the perusal of these 800 pages. It was suggested in the inaugural article of this RevLew that, if history be understood in its highest and broadest sense, the bishop of Durham and Sir Henry Maine, perhaps more than any writers of formal histories, are the leading English historians of the present day. It is impossible not to regret that an historian who is not anworthy of comparison with the bishop of Durham as an historical investigator of unfathomable learning should fall so far below him in the power of lucid exposition and historicel constraction; but the subject has been so long the happy hunting-ground of the imaginative historical picture-painter and the polemical theorist that it is perhaps well that the new epoch in the study of university history-possibly even of medieval church history generally-should be inaugurated by a writer whose pleasure and interest in his work come out chiefly in the grim delight with which he demolishes the ingenious constructions of the philosophical historians who (as he is never weary of complaining) undertake to write history $a$ priori.

The subject is one which is so unfamiliar to the mass even of professed students of history that some account of the main facts which have been established with reference to the portion of the subject indicated by my title will probably be more interesting to the reader than a formal review of Denifle's great work.!

The word universitas is one to which a false explanation is often assigned for polemical purposes by controversial writers, while the true explanation of it at once supplies us with a clue to the nature and historical origin of the institution itself. The notion that a university means a universitas facultatum-a school in which all the faculties, or branches of knowledge, are represented-has, indeed, long since disappeared from the pages of professed historians, but it is still persistently foisted apon the public by eminent writers

1 It will be convenient to state that the main conclusions indicated in the following pages were arrived at independently. The friter has, however, freely availed himself of lather Denifle's researohes, which be is glad to flnd more often confirm than correct the results of his own. He has endesponred to scknowledge his obliga. tions to father Denifle, but he is often indebted to him even where he has not altogether accepted his conclusions. 
with whom history is subordinate to edification. ' However imposing and stimulating may be the conception of an institution for the teaching or for the cultivation of universal knowledge, however imperative the necessity of such an institution in modern times, it is one which can gain no support from the facts of history. The word ' university ' means merely a number, a plurality. ${ }^{2}$ Universitas vestra in a letter addressed to a number of persons means merely 'the whole of you ;' in a more technical sense it denotes a legal corporation; in the language of the Roman law it is the synonym of collegium. At the beginning of the thirteenth century we find the word applied to the rising corporations either of masters or students ; but the word long continued to be applied to other corporations as well, particularly to the guilds in towns, while as applied to scholastic guilds it is at first ased interchangeably with such words as communitas or collegium, and in the earliest period it is never used absolutely. The phrase is always universitas scholarium, universitas magistrorum et scholarium, universitas juristarum, universitas artistarum, and the like. It is a mere accident that the term has gradually come to be restricted to a particular kind of guild or corporation, just as the terms 'convent,' 'corps,' ' congregation,' ' college' have been similarly restricted to certain specific kinds of association. It is particularly important to notice that the term was, in the middle ages, most frequently ased distinctly of the scholastic body-whether of teachers or scholars-not of the place in which such a body was established or even of the collective schools of such a place. ${ }^{3}$ The word used to denote the town or the sehools of a place was studium rather than universitas. To be resident in a university would be in studio degere or in scholis militare. The term which most nearly corresponds to the vague and indefinite English notion of a university as distinguished from a mere school, seminary, or private educational establishment is not universitas but studium generale; and studium generale meant not a place where all subjects were studied, ${ }^{4}$ but a place where students from all parts were received. ${ }^{\circ}$ As a matter of fact very few medieval studia possessed all the faculties. Even at Paris the civil

' See es. cardinal Newman's noble Idea of a Univeraity, p. 20, and the archbishop of Canterbury's The Seven Gifts, p. 13, where 'nniversity ' is explained by uriversitas scientiarum. It should be said that the cardinal admits that this may not be the original meaning of the word, which, he says, is ' unknown.'

'In patristio Latin universitas means 'the universe.' At lesst one mriter has been led by this ambiguity to antedate the origin of anivarsities by some six or seven centaries.

- The distinction was more gtrictly maintained at Paris than at Oxford.

- A school of nniversel learning' (Nemmsn's Hist. Sketches, 1872, p. 6). So Haxley, Science and Culture, p. 31.

- In this respect it may be compared with our term 'publio school,' though of course a studium gererale was always a place of higher edacation. 
law cessed to be taught in 1219 , and Bologna had no theological faculty till 1960 .

The university, then, was originally a scholastic guild, whether of masters or of students. These guilds sprang into existence, like other guilds, without any express authorisation of king, pope, prince, or prelate. They were spontaneous products of that instinct of association which swept like a great wave over the towns of Europe in the course of the twelfth century. Only after certain universities-chiefly Paris and Bologna-had acquired a kind of oecumenical recognition and prestige did it come to be recognised that a studium particulare could not be converted into a studium generale, whose degrees should be entitled to universal respect, without a deed of erection from either the pope or the emperor. From this time forward the term studium generale acquired the more definite and technical signification of a studium which possessed, either by custom (established before c. 1250 A.D) or express privilege, the right of bestowing on its masters the facultas ubique docendi. ${ }^{1}$

In view of the spontaneous and voluntary character of the original universities we should be prepared to find, amid certain common features of constitution and organisation characteristic of the age in which they arose, at least as much variety as may be found in the constitutions of the trade guilds and craft guilds, or again in the municipal corporations or the national estates of different parts of Europe. As a matter of fact, however, at the exact moment at which the association-movement reached the scholar class the conditions necessary for the formation of universities existed only or preeminently in two places-at Paris and at Bologna. These, the first two universities ${ }^{2}$-the only original universities-were formed at about the same time (the exact dates will be discussed hereafter) by the masters of Paris and by the students of Bologna. Every university (in the academic sense) that has come into existence from that day to this has been a more or less close imitation of one or other of these typical organisations. The fame of the schools of Paris and Bolognes was so transcendent, and the intercommunion of the great centres of education of the thirteenth century so close, that their universities supplied the model to all others. In the case of the earliest aniversities the imitation was, with more or less adaptation to local circumstances, conscious and deliberate; while the latest, the most modern, the most purely utilitarian of modern

1 On the whole question see Denifle, i. 1-29, 768-791. A studium genorale for a partioular country (roppectu regni) could be established by any king or sovereign prinoe. AB a general rule universitates existed only where a studium generale (at least respectu regni) existed, but the rule was not universal; and it was for the establishment of the studium generale, not of the uriversitas, that the papal or imperial brief was sought.

Strictly speaking, there was at Bologne not one university, but several. See below, p. 663 t. 
European universities retain constitutional features, institutions, offices, ceremonies, for the explanation of which it is necessary to go back to the customs and asages either of the Bologna students or of the Parisian masters in the latter half of the twelfth centary A.D.

The causes of the aggregation of scholars in the two cities of Paris and Bologna during the twelfth centary as well as the origin of the great guild movement, which led to their incorporation into universities, mast be sought in that mysterious awakening of the human spirit which began in the eleventh century and reached its full development in the twelfth. The intellectual movement which calminated in the rise of the aniversities was but one side of a general revivification of the human spirit, which found its expression in every department of human life-in the crusades, in the revival of monasticism, in the revival of political and municipal life. For once a date does seem to occupy in actual history the place which it now occupies only in the pages of historians. The 1000th year of grace, which had been anticipated with terror as franght with apocalyptic woes, marks the turning-point between the properly 'dark' ages of European history and the period of medieval civilisation.' This was the turning-point, but it is not till the end of the centary that.a marked and definite revival of education becomes traceable. The two archetypal universities owe their existence to two different currents of the mighty stream of intellectual movement which now set in. In Italy the renaissance showed itself above all in a reawakening of political activity; and there the revival of education centres round the teaching of the Roman law by Irnerius at Bologna. North of the Alps society was more completely feudal and its civilisation more completely ecclesiastical. The new intellectual life of the period consequently took the form of a revival of theological and dialectical speculation, which eventually became centralised in Paris.

Fabulous as is the connexion between the Palatine schools of Charles the Great or of Charles the Bald and the schools of Paris, some of the features which distinguish the Parisian from the Italian university system can really be traced back to the legislation of Charles the Great. Before his time education had been practically confined to the monasteries and the episcopal schools, simply because the class of lay teachers and of lay learners had alike died out in the utter decay of cultare and civilisation which the completion of the barbarian conquest brought with it. In countries where the barbarians formed the main part of the population, and where the Roman civilisation was less deeply rooted than in southern Europe, as, for instance, in northern France, the church was the only one of the institutions of the old Roman world which survived. What

' Cr. Mullinger's Cambridge, i. 45, 
little knowledge and what little education survived were to be found in the monasteries. The revival of education by Charles stereotyped this connexion between the church and education. The monastic and episcopal schools were resuscitated, teachers were encouraged, and the claims of education were considered in the distribution of patronage. The immediate fruits of this revival of education were not brilliant, but they were permanent. Till now England and Ireland had boasted far more famous schools than any that were to be found in continental Europe north of the Alps. The removal of Alcuin from the school of York to the Palatine school of Charles marks the transference of the primacy of letters from the British Isles to Gaul. From Alcuin to Abelard the torch of dialectic tradition was continuously handed on : though once and again it flickered very low, it was never allowed atterly to die out. No one place was the seat of this dialectical activity ; but all through the dark ages that intervene between Charles the Great and the twelfth century there were always at least one or two monasteries or cathedrals where the fame of some great teacher drew students from distant regions, and where some ray of genius, some spark of controversial fire infused a little life into the traditional curriculum-the little fragment of Aristotelian logic, the dull compendiums of old-world learning, and the dogmatic teaching of 'positive' theology.

Thus, at different times, Falda was made famous by Rabanus Maurus, Auxerre by Heinric and Remigius, Tours by Gerbert and Berenger, Chartres by Bernard and William of Conches, Bec by Lanfranc and Anselm. During the earlier portion of the period which these names cover, Paris was not even one among the educational centres of France. It is not till the first years of the tenth century that the very existence of any schools whatever at Paris becomes a matter of history. Remigins of Auxerre is the first master who is known to have taught at Paris. The learned authors of the 'Histoire Littéraire de la France' find in the school of Remigius le premier bercean de l'université de Paris.' But for a century after the time of Remigins the atmost diligence of an historian possessed with the most infatuated belief in the primeval antiquity of his alma mater has only succeeded in collecting three or four names of masters or scholars who can be shown on decent authority to have taught or studied at Paris. ${ }^{8}$ At the close of the tenth century the cessation of the Danish devastations and the appointment of regular abbots in the place of the lay nobles who had usurped their place may have produced some improvement in the monastic schools. ${ }^{8}$ From the beginning of the eleventh century

1 Tome vi. 100.

2 Bolens multiplies the list indefnitaly by assaming that everyone who stodied in France from the ninth century onfards studied at Paris.

Bist, Lith vi. 20. 
the names of clerks mentioned as having taught or studied at Paris become somewhat more frequent; but they are not names of any great distinction. It is not till quite the close of the century that anything like a stream of scholastic migration begins to be directed towards Paris. William of Champeanx, the master of Abelard, is the first Parisian master who left his mark apon the development of the scholastic philosophy, while it was the world-wide reputation of the wandering Breton scholar whom William's fame attracted to the cloisters of Notre-Dame that created for the schools of Paris the unique prestige which they retained throughout the medieval period.

The less imaginative historians of Paris have generally been content to trace its origin to his time; and it was no doubt the teaching of Abelard that marks at once the full development of the twelfth-century renaisance and the elevation of Paris to the position of the intellectual metropolis of Europe. From the time of Abelard the scholastic fame of Paris became, unlike the reputation of mere cloister schools like Bec and Fulda, permanent and independent of the reputation of any single teacher. No one of Abelard's immediate successors was distinguished by the same extraordinary charm of manner or by the same variety of gifts. Whereas the most famous of the old episcopal or monastic schools had owed their fame to a single master, Paris rapidly became a city of teachers. But the academic position of Paris was not made by Abelard as the fame of Bologna was made by Irnerius. Abelard had been himself caught by the centripetal tendency. His unparalleled reputation undoubtedly accelerated the movement, but the scholastic aggrandisement of Paris corresponds at every step with the growth of the commercial and political importance of the ancient stronghold of the dukes of the French. The history of the Parisian schools begins with the expulsion of the Normans. Their development culminates in the growth of the university proper during the brillient reign of Philip Augustus, the patron of citizens, the enlarger of the Parisian pomorium. Alone among the older university towns Paris was a great capital. Paris occupied, indeed, more completely the position of a modern capital than any other thirteenth-century town in Europe. That it did so has been the factor which has more than any one other cause differentiated the history of France from that of other European states; and the same fact accounts for the unique prestige which the schools of Paris occupied in the medieval world. The position of the university was an accident of the political position of the city; while the political position of the city and of the French monarchy itself was immensely strengthened by their close connexion with a spiritual power which could hold its own even against the papacy. 
While the foundations of this scholastic greatness were laid in the days of Abelard there was nothing in the organisation of the schools in which he taught to distinguish them from any other church schools. There, as elsewhere, the teacher had to obtain the license of the church. At Paris there were, in the days of Abelard, three great charches from which the requisite authorisation could be obtained-the cathedral, the collegiate church of St. Geneviève, and the abbey church of the Canons Regalar of St. Victor. The schools of St. Victor became the chosen home of the anti-scholastic or mystical theology, and more and more drifted away from the dialectical movement, the triumph of which was sealed by the rise of the universities. In the time of Abelard the cathedral was the chief secular school of theology, the Mount of St. Geneviève the seat of the schools of the artists. It had been common to represent the university as the result of a fusion or federation of the Arts schools of St. Geneviève with the theological schools of Notre-Dame. As a matter of fact, howerer, the last trace of the famous schools in which Abelard taught is lost before the middle of the twelfth century. In 1147 the secular canons of St. Geneviève were supplanted by canons regular from St. Victor's and St. Martin's-in-the-Fields. Henceiorth we hear of no school at St. Geneviève but a cloister school of theology taught and attended only by members of the house, like the cloister school of St. Victor.' The schools in connexion with which the university arose were confined to the old island cite and the bridges across the Seine. It is not till the second decade of the thirteenth century that we find masters again crossing to the left bank of the river, and passing from the jurisdiction of the chancellor of Paris to that of the abbot of St. Geneviève $;^{2}$ and it is not till 1255 that we hear of a chancellor of St. Geneviève, appointed by the abbot to confer the licentia docendi on candidates who wanted to open schools on the 'Mount.' 3 The original university was formed exclusively by the masters who taught in the island ander the chancellor of Paris. The university was an outgrowth of the cathedral schools, and of

1 This is proved conclusively by the letters of Btephen of Tournay, abbot of $8 \mathrm{t}$. Genevieve (1176-1191). I owe the correction of the universally received vier on this subject to father Denifle (i. 656-664).

Denifle, i. 665.

- Denifle, i. 669. Though in $1227^{\circ}$ (Balmas, iii. 124) doctors of theology and dearees were allowed with the license of the abbot to lecture in the territory of $8 \mathrm{t}$. Genevidre, the chancellor of Bt. Genevidve in practioe conferred the license only in arts, and was always specially connected with that faculty. He was alwrys much more completely ander the control of the faculty then the chancellor of Notre-Dame. As the ner chancellorship did not materially affect the constitutional development of the univeraity, I shall not allade to the sabject again; but one cannot help remarking that the fact of the existence of two chancellors at Paris ought alone to have precerved English writers from identifying the position of the cathedral chancellor (rhom they persist in calling ' chancellor of the university of Paris ') with that of the chancellor of Oxford. 
them only. To understand the position of the chancellor of Paris is, therefore, essential to the comprehension of the complex academical polity which grew up round the simple institution of the licentia docendi.

At a time when no church would be likely to boast more than one or two masters at once, these masters might or might not, it would appear, be members of the capitular body according to circumstances. With the revival of education in the eleventh century, however, we find a tendency to make the 'master of the schools,' as he was called, a regular member of the cathedral body ; ${ }^{1}$ and eventually a canon of the third Lateran council in 1179 required the endowment of the mastership with a ' competent benefice' in all cathedral churches. ${ }^{2}$ This was effected in one of two ways. Either the new dignity of scholasticus was created or the duty of presiding over the schools was annexed to some existing office-sometimes to the archdeacon's stall, more frequently, as at Paris, to the chancellor's. The primary duties of the chancellor were analogous to those of a royal chancellor, viz. to keep the chapter seal and to draw up letters and documents which required the seal to be affixed to them. As this function required an amount of education which was not a matter of course in canons of that period, it was natural enough that the supervision of the schools, and again the care of the library, should be entrusted to the same functionary. ${ }^{8} \mathrm{As}$, however, the mastership of the schools passed into an ecclesiastical dignity, its possessor seems to have become almost as anxious to delegate his educational duties to others as the canons were to transfer their troublesome choir duties to vicars or petty canons. And with the spread of education there were increasing numbers of professional teachers, who were anxious to obtain authorisation to teach for their own profit under the shadow of some great church. Hence it became usual for the chancellor or scholesticus to grant a regular permission to such masters to teach under his authority.

In 1138 we find a council at London forbidding the growing practice of selling such permissions. ${ }^{4}$ At the third council of Lateran in $1179^{5}$ a still more important step was taken. Not only

1 Numerous instances of this transformation in the position of the magister scholarum are given in Hist. Litt. t. ix. p. 81.

- Balmas, ii. 430.

- The eupervision of the 'petty' or elementary grammer schools of the place wes sometimes entrusted to a different dignitary. At Paris masters or mistresses of these Bchools were licensed by the ahanter.

4 Balmas, ii. 155; Labbe's Concilia, ed. Florentiø, 1759, t. xi. p. 614.

- Bulous, ii. 480, confirming the decretal of Alexsnder III (ib. B70-1). Crevier (Histoire de l'Univ. de Paris, i. 256) confounds the provisions of these two councils. It is doubtful whether the canon of the council of Rouen referred to by Hist. Litt. t. ix. p. 82, and by Crevier, vii. 108, has anything to do with edacation. Populum docere probably means ' to preach.' 
are the presiding masters of the church schools forbidden to take any fee or reward for granting the licentia docendi-as the permission is now called-but they are compelled to grant the license to every duly qualified applicant. The control of the chancellor over education on the one hand, and on the other the right of the cumpetent teacher to the license, form the basis of the French university eystem. The control of the chancellor distinguishes it from the Italian system; without the corresponding right a university could not have come into existence at all.

In the age of Abelard even this right of the teacher to the license was not yet established. We see him long prevented from teaching in Paris at all by the jealousy of his master, William of Champeaux. The school of Paris was still only a cloister school; the monopoly of the magister scholarum was not yet shaken. Still less was there the smallest trace of anything approaching a university of masters. The only germ of the future university that we can trace in his career is the faintly indicated existence of certain professional customs and unwritten laws which in the next generetion formed the basis of a rudimentary society of teachers.

That nobody should teach without having been himself taught by some duly authorised master was almost too obvious a principle to need formal enactment. That he should not enter upon his work as a teacher without his former master's sanction and approval was an almost equally natural piece of professional etiquette. When Abelard, already a famous teacher of dialectic, wanted to become a theologian, it was considered necessary for him to put himself under a master again. He accordingly became the pupil of the most famous theological teacher of the day, Anselm of Lran. The great philosopher, however, soon grew impatient of the instractions of an aged master of whose abilities he had formed the lowest possible estimate. ${ }^{1}$ He cessed to attend lecture regularly, and at length, in the course of conversation with fellow students, frankly expressed his surprise that men who had received a literary education should not be able to study the scriptures for themselves, without any other aid than the text and the usual 'glosses.' The unheard-of doctrine was received with derision, and Abelard was jestingly challenged to make the attempt. He took the scoffers at their word, and offered, if they would provide him with a standard commentary, to lecture on the most difficult book of the Bible that they might choose the very next day. They selected the book of Ezekiel, but Abelard falfilled his promise. The performance was at first treated as a mere piece of bragga-

1 Accessi igitur ad hanc senem, coi magis longerus usus quam ingenium vel memoria nomen comparaverat. Ad quem si quis de aliqua questione palsandum accederet incertus, redibat incertior.' (Abelarà, Historia Calamitatum, osp. 3.) He aftertrards compares him to the barren fig-tree of the Gospel. 
docio, but the lecturer went on, and the self-taught theologian ere long became as formidable a rival to Anselm as he had before proved to William of Champeaux. His teaching was, however, treated as irregular and even illegal, not only because he had not been duly licensed but because he had 'incepted ' or begun to lecture 'without a master.' He was obliged to leave Laon, and his conduct on this occasion formed a distinct article of charge against him at the council of Soissons ${ }^{1}$ in 1121.

The opening of this course of lectures on Ezekiel seems to be spoken of as a formal and public assumption of the magisterial office, and as requiring the sanction of the new teacher's master. How far in Abelard's time the ceremonies which attended later ' inceptions' were observed, it is impossible to say. But it is at least quite possible that some of them may have been of great antiquity; possibly they may even have been handed down to the universities of the middle ages from the schools of the old Roman world. At all events a clear understanding of the idea of the 'inception' is essential to a comprehension of the very nature of a university of masters. It was out of this custom that the universities of masters ultimately grew.

The idea of 'inception' involved two elements. It was the formal entrance upon his office of a duly licensed master, and his recognition es such by the existing members of the profession-his reception into the teaching brotherhood. The new master was first set free from the subjection of pupillage ${ }^{2}$ by having the magisterial biretta placed upon his head-the old Roman ceremony of manumission-by his former master or the master ' under whom ' he was said to incept. He then gave a formal inaugural lecture, after which proof of professional capacity he was welcomed into the society of his professional brethren with appropriate speeches, and took his seat in the magisterial cathedra. The idea that a new

1 'Quod aine magistro ad magisterium divino lectionis acoedere prasnmpaisset' (Bulsus, ii. 66). In the words 'Quod nec pontifinis nec ecolesim suctoritate commendatas legere pablice prosumpseram,' trom Abelard's Hist. Calam., Bulmus (i. 284, ii. 67, 669) relies opon a corrupt text. The printed text omits 'enm,' i.e. librum, atter 'suotoritate' and changes commendatum into commondatus. The notion that the chancellor conferred the license in the name of the pope is much later. Bee Denifle, i. 765.

-The 'birette' was also regarded as the most important of the insignia of the offlce. Bachelors taught uncovered. At Bologna a D.CL. receized a book and a ring. In the English aniversities in the fitteenth century the master of grammar on inception recoived as the symbol of his office a birch, while instead of delivering a epecimen leseon he entered at once upon a more essential and characteristio part of his duties by flogging a boy within the precinct of the achools. The beadle was paid a groat for the birch, and the boy a similar som 'for hys labour.' See Mullinger's Cambridge, p. 844. The ceremony supplies an excellant illustration of the fondemental ides of an inception. An exoellent anslogy is afforded by the ceremony with which a Bcotoh judge is admitted to his oftloe. He first presents his patent, then tries two ceses and reports his decision to his brethren, after which proof of capacity he is sworn a "senator of the College of Justice.' 
comer should 'pay his footing' seems almost a primitive instinct of human nature. It formed an essential part of inception that the ' inceptor' should entertain at a banquet the whole or a considerable number of his new colleagues. In some cases presents of gloves or gowns had also to be made ; and gradually contributions in money to the funds of the society were exacted, in addition to the presents to its individual members-an exaction which has ever since been the inseparable accompaniment of degree-taking in all universities, medieval and modern. The whole affair was originally nothing but a piece of unauthorised buffoonery-hardly more dignified or important than those sometimes brutal and sometimes silly stadent initiations which the masters of later times tried to stamp out by every possible penalty, and which still linger on in bad schools and in the ateliers of modern Paris. ${ }^{1}$

Out of this custom, however, the idea of a guild or corporation of teachers in all probability arose, as perhaps other guilds may have arisen from similar initiations. Gradually, and probably by imperceptible steps, the ceremony passed from a mere jollification or exhibition of good-fellowship into the solemn and formal admission of a new master into an organised and ultimately all-powerful corporation of teachers. And the trades-union of teachers rapidly succeeded in acquiring a monopoly of the trade. 'Inception ' became as necessary to the teacher as the chancellor's license. The 'licentiate' was not regarded as a full 'master ' or 'doctor ' 2 till he had 'incepted.' 's

1 It is not impossible that the matisterial initiation was partly copied from the student initiation, which wes certainly of great antiquity. Gregory Nazianzen gives an

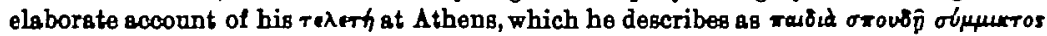
-Or. xliii. ed. Migne, t. xrrvi. pp. 515, 516. Photins, on the enthority of Olympiodoras (fifth century), declares that apon receiving his palliwm the new teacher was required to give a banquet to the existing professors ('Axpowpltau). Dee Migne, t. ciii. p. 269. An edict of Justinian forbids practical jokes-an integral part of the rodert-on treshmen in the law schools (ibid. 449). In medieval Paris trequent statutes were passed against the exaction of money from bajauri-becs-jaures, yellowbills, i.e. unfledged birds (Bulmus, iv. 266). In the sixteenth century the practice of initisting bejauni pessed into the brutal ceremony of (cornurm) dopositio, which Melanohthon is said to have defended.

It is perhapa hardly necessary to notice that originally the titles magistor, dactor, professor were absolutely 8ynonymous. Magister was originally the most nsual term (though all three were used) except among the Italian lar teachers, who specially affected the title of doctor. From thence it passed to the doctors of las at Paris and other oniversities, and erentually (much later) it came to be usual to apply the name to magters of all the superior faculties, and in Germany to those of the faculty of arts also. The German Ph.D. is, of conrse, merely the equivalent of our hamble M.A. How complete an accident is the appropriation of one or other of such titles to particular toculties is shown by the fact that the musical graduate, who (in spite of his gorgeous plumage) rants below the M.A., is designated doctor. The title 'professor' was, in the middle ages, used as an occasional synonym for master or doctor in all faculties, though eventually restricted to salaried masters. It is to be regretted that the universities of Cambridge and London should have perpetrated the historical solecism of giving three degrees in the same faculty-doctor, master, and bachelor. If there are to be three degrees, the intermediste one should be licentiate.

The ides that a man was not fully invested with an offlce till he had entered 
Another great institution which was a development of the same root idea was the institution of chivalry. The original conception of knighthood was the solemn reception of the novice into the brotherhood of arms. The blessing of the priest was required by the knight bachelor as the scholastic bachelor required the license of the chancellor; but it was by the touch of the veteran's sword that the candidate received his actual initiation into the soldier's profession, as it was by the veteran master ' that the licentiate was admitted to full membership of the teaching brotherhood. ${ }^{2}$

Any one who reads the formulw still used in conferring degrees in our own universities ${ }^{3}$ will see that the ceremony commonly called 'taking a master's degree' is in reality the ceremony of receiving the chancellor's license to 'incept.' Though the ceremony of inception has disappeared, the inceptor does not become a master of his faculty or take his seat in convocation as such till the beginning of the following term. The 'commencement' of the Cambridge calendar still remains as the last relic of the forgotten ceremony of the new master's inceptio or principiun. In the Scotch universities the ceremonies of license and of inception seem to have been merged into one, and candidates still receive their degrees by birettatio at the hands of the chancellor.

We now approach the question which it is the main purpose of this essay to answer. When did the university of Paris originate, and by what steps did it attain the complex constitation which has more or less formed the model of all universities of teachers down to the present day ? It is hoped that by this time one thing has become clear-that the growth of schools and the multiplication of

upon its duties was derived from the Romsn law. Cf. Hatch's Organisation of the Early Christian Churches, pp. 181, 182.

${ }^{1}$ In the faculty of theology the birettatio was performed by the chancellor, who was himself ex offioio a doctor of theology.

The word bachelier (in Latin baccalareus, bachollarius, or baccalaurous), of which many absurd derivations are still repeated, meant originally ' youth ' or ' apprentice,' both notions being apparently involved in the word. In the schools it originally meant a scholar who was an epprentice or candidate for the mastership. It was especially applied to a scholar who was allowed to give loss formal or 'oursory' lectures in the school of a master. Gradually the conditions on which a stadent might be so admitted were flxed by the aniversity or its facalties, and stodents who had passed the requisite examinations or performed the required exercises Fere formally admitted to the degree by the head of the oniversity or faculty. The chancellor of Paris never had anything to do with the admiasion to this degree; at Oxford and Cambridge the chancellor made bachelors becanse he was head of the university proper as well as the bishop's representative.

- Ad honorem Domini nostri Jesa Christi, et ad profectum sacrosancta matris ecolesin et stadii, ego auotoritate mes et totiug nniversitstis do tibi licentiam incipiendi in froultate Artium (vel facultate Medicinm, Jaris, 8. Theologio), legendi, disputendi, et cotars omnis tociendi, qu田 ad statum Doctoris (vel Mseistri) in esdem facultate pertinent, cum completa sint qua per statuta requiruntur; in nomino Domini, Patris, Pilii, et Bpiritas Bencti.' (Statuta Universitatis Oxonionsis, Oxonii, 1877, p. 144.) 
stadents in a particular town do not imply the existence of a university. In the Paris of Abelard or of John of Balisbury there Was no more a university than there had been in the Athens of the age of Pericles, or the Rhodes of the age of Cicero, or the Byzantium of the time of Basil. Even of the custom of inception there are but the faintest traces, and there is perheps some foundation for the tradition which connects the increasing importance of this ceremony with the age of Peter the Lombard.' At all events it was at about this time that the honours of the magisterial chair began to be an object of ambition to students who had no intention of devoting themselves, or at all events of permanently devoting themselves, to the teacher's profession. The consequences of the rising passion for 'degrees,' as they were afterwards called, were particularly important in the faculty of arts. In the days of John of Salisbury 'grammar' and philosophy were taught and studied as seriously and earnestly as theology. The teachers were mature scholars who looked upon teaching as their life's .work. The students studied for long periods. After the middle of the century the passion for graduation, together with the absorbing enthusiasm for scholastic theology and the canon law, caused the instruction in the Latin language to be reduced to a minimum, while the mastership even in the philosophical faculty was looked upon as the natural preliminary to procoeding in one of the higher facultiestheology, law, or medicine. Hence the enormous multiplication of masters, and of young masters, which is the immediate cause of the growth of the university of Paris.

One passage, and one only, in all the chronicles and documents of the period affords evidence of the existence of anything like a university at Paris before the beginning of the thirteenth century. In Matthew Paris' life of John de Cella, abbot of St. Albans, we are told that the subject of the biography was, as a young man, a student at Paris, and was there admitted into the 'fellowship of the elect masters.' 2 The abbot died 'full of days' in 1214. He may, therefore, be assumed to have become a master not much later than 1170 or 1175 A.D. At about that date, then, the society of masters had some kind of existence, however indefinite, inchoate, and rudimentary. The complete silence of John of Salisbury, whose works are full of reminiscences of student life at Paris, will

1 The traditional story is that academical degrees were either invented by Peter the Lombard, or by Irnerius or Gratian and brought to Paris trom Bologna by the Lombard (Balmas, ii. 681, 682).

1 'Bio in jurentate soholaram Parisiensium trequentator aseiduns ad electoram consortium magistroram meroit attingere' (Bulson, ii. 502). The possibility should be allowed for thet Matthew Paris, writing at a time when the university was fally grown, may have desaribed the fact that John de Cella became a mester of arts in langaage more saitable to the asages of his own time. Still the language ased is not partioularly toohnical, and the statement must probably have been based on wome statement of the abbot, whose papil Matthem Paris wes. 
not allow us to place the first beginnings of the university earlier than 1147-the probable date of his departare from Paris. It is, therefore, a fairly safe inference that the period 1150-1170-probably the latter part of that period-sew the birth of the university of Paris. We must beware, however, of exaggerating the extent and definiteness of the association of which the ase of such an expression as this implies the existence. It proves little more than the fact that it was customary for a master, after being licensed by the chancellor, to be formally initiated into the society of his fellow masters. It points to the existence of meetings of the masters for the celebration of these 'inceptions,' and probably also for disputation, and perhaps apon rare emergencies to concert measures for the vindication of an injured colleague or stadent, ${ }^{1}$ for the punishment by expulaion or professional excommanication of a breach of professional etiquette, or for the pursuit of some similar common. object. But two facts are \& sufficient indication of the amorphous and merely customary character of the bond which held together the guild into which the masters of Paris were spontaneously, and perhaps almost unconsciously, constituting themselves. Till circa 1208 A.D. the university had no written statutes, and till a considerably later period no head or presiding officer.

The evidence for the first of these assertions is a brief of Innocent III sanctioning the restitution to the society of a master who had been expelled from it for breach of certain statutes recently made by the society and sworn to by all its members." The actual text of the statutes is not preserved, but it appears from the brief that they were three in number. The first regulated the dress of masters, no doubt prescribing the ' round black cope reaching to the heels at least when new,' mentioned in one of the earliest extant statutes; the second relates to the observance of 'the accustomed order in lectures and dispatations ; ' the third required attendance at the funerals of decessed masters. From the extreme simplicity of these regulations, and the fact that their enactment is spoken of as something new, it is abundantly evident that they were the first ever formally made by the society-the first reduction to a written form of the establighed but hitherto unwritten customs of the profession. The momentous step-for such it proved in its ultimate consequences -must, therefore, have been taken in the year 1209 or not much esrlier. It is, indeed, a question whether the 'foundation' of the university, in the modern sense of the word, may not be ascribed with more truth to the decade 1200-1210 than to the years 11501170. At about the same date the university acquired recognition as a legal corporation. A brief of Innocent III empowers the society to elect a proctor, i.e. a syndic or common procurator ad litem, to represent it in the papal court. By this permission the society 
obtained in modern language the right to sue and be sued as a corporation. ${ }^{1}$ It must not, however, be supposed from this that, according to the ideas of the time, a charter from either pope or king was considered to be indispensable to enable a private society to acquire a legal corporate existence. The ideas of the Roman law were at this time so widely diffused that it was generally recognised that members of any profession or trade had an intrinsio right to form themselves into a guild or collegium, and to make statutes or bye-laws binding without any farther authority upon its own members. Thongh Paris lay in a pays de droit coutumier, the idea of the Roman empire had so sunk into the medieval mind that the principles of the Roman law wherever they became known were treated almost as a kind of jus divinum or jus natura, whose validity was independent of any express enactment of the local sovereign. It was just this fact which afterwards made the French and English kings so jealous of the civil law and the common lawyers so jealous of the civilians. But at present the study of the Roman law was encouraged at Paris by Philip Augustus; and it was moreover everywhere to some extent admitted in its application to ecclesiastics, such as the clerks of Paris."

Thus Innocent expressly recognises the inherent right of the masters to a corporate existence, both in the brief authorising them to appoint a proctor ${ }^{3}$ and in the brief sanctioning the readmission of the expelled master. In the former case, the pope was called upon to dispense with the obligation of the oath which the masters had taken to refuse their consortium to all offenders against the statutes. In the latter, the necessity for appointing a proctor arose from the suit in which the society were engaged against the chan-

' Bulmus, iii. 28, sub anro 1208. Denifle, no doubt rightly, connects the brief with the suit of 1210-11 (i. 86).

2 See Bsvigny, Gasch des rom. Rechts im Hittolalter, Heidelberg, 1834, ii. 274-5. For the ideas of the medieval jurists on the subject of collegia see Denifle, i. 191, 192, 169-76. The fact that ecolesiestion conld form corporations with the appropal of the ecclesiastical anthorities, bat without rojal charter, is illustrated by the practice of bishops incorporating colleges of priests-vicars (see e.g. Freaman's Cathodral Church of Wells, p. 187 seq.) Bo in 1847 the chancellor of Oxford incorporates the berber surgeons (Wood, Hist. and Antiq. of Oxford, i. 448, 414), who enjojed the privilege of the univeraity. The best eccount of the origin of the university as a roluntary sooiety is that given by the masters themselves in their letters to the prelstes of Christendom in 1258 or 1254 (Buleus, iii. 255). 'Magistri reverendi vita et doctrina olarissimi, mente religiosi, omnes tamen degentes in habitu seculari, qui processa temporis crescente namero saditorum, sicut oportuit, amplisti, at liberios et trar:quillius vacare possent studio litterali, si quodam essent juris apecialis vinoulo collegati et sosiati, corpus collegii sive universitatis cum maltis privilegiis et indultis ab atroque prinaipe sunt gdepti' (Bdena, iii. 256). In the controversy with the men. diesnts they even denied the right of the pope to meddle with the nniversity, qua oniversity, at all. 'Quia secandam joris civilis ordinstionem nullas ad societatem compelli debet,' \&c. (Buløus, iii. 649).

' Licet igitur de jare commani hoc fecere valeatis,' do. (Balmas, iii. 28). 
cellor and church of Paris, to whom the claims of the new organisation seemed inconsistent with the allegiance of the individual masters to the chancellor. Hence to secure from the pope formal recognition of their proctors was to win half their case.

The history of the university during the early part of what may be called its documentary existence is one long struggle with the chancellor of Paris. The university, in fact, may be said to have grown into a legal, autonomous corporation from the necessity of resisting the oppression or usurpations of this offcial. Opposition to the chancellor was its chief or sole raison d'être. A clear understanding of the original relations between the university and the chancellor is, therefore, absolutely essential to the appreciation of the constitution of the full-grown society. We have already spoken of the chancellor's power to grant the license. At present the masters as such had no control over the chancellor in the exercise of this prerogative. The chancellor gave or refused the license at his own discretion, though canonically bound to grant it gratuitously to all competent teachers. But, in spite of prohibitions, the chancellor continued to exact fees. And his functions were not limited to the grant of the license. In France all students were assumed to be clerks. As such they enjoyed the same immunities from the secular tribunals as persons actually in orders. In later times the bishop's court was the ordinary tribunal for the trial of charges against a scholar; but in the beginning of the thirteenth century the chancellor exercised (concurrently with the bishop and his 'official') an extensive jurisdiction in civil, criminal, and spiritual cases over the masters and scholars. He possessed the power of excommunication and a special prison for the confinement of criminous clerks. He was a kind of extraordinary 'official' for students. On the other hand in the university as such the chancellor possessed no status whatever. He was not a.s such a member of it. ${ }^{1}$ To suppose the position of the chancellor of Paris at this time to have been analogous to that of the modern chancellor of Oxford is completely to misconceive his position. In the middle ages he was never described as chancellor of the university, but always as chancellor of Paris or Beate Virginis. The university was, as has been said, a society formed more than anything for resisting his despotism. In the power of recognising or refusing to recognise the 'inception' of a new master the university possessed an equivalent to the chancellor's power over the license. The university could not prevent the chancellor from licensing whom he would ; but the university could refuse to admit as a member a licentiate who had not complied with its own conditions; it could refuse to admit him to inceptions, disputations, and similar gather-

' So the university alleges in 1381, 'que comme chancelier il n'est pas membre de l'université, mais comme maistre en arts ' (Buløus, iv. 609). 
ings; it could refuse his pupils admission to the lectures of its members, and it could threaten with a similar ban espirants to the mastership who should attend the offender's lectares in spite of its prohibition.' Each party-the chancellor and the oniversity-tried by the use of its undoubted prerogatives to nullify in practice the prerogatives of the other. Had the parties been left to fight the matter out with their own weapons, the chancellor, backed by the whole weight and inflaence of the bishop and chapter of Paris, and armed with judicial authority, both spiritaal and temporal, might possibly have crushed the nascent university or reduced it to dependence upon himself. 'Coercion' might have prevailed against ' boycotting.' But the interference of the holy see more than neatralised this superiority of the chancellor. The papacy, with its accustomed segacity, took the side on which lay the promise of the future. Except where the privileges of the university interfered with those of a still more favoured body, the mendicant friars, the authority of the papacy was almost uniformly exerted on behalf of the university and against the chancellor.

The first of a long series of briefs directed against the chancellor's sbuse of his powers bears date 1210. From this brief ${ }^{2}$ and the agreement drawn up in consequence of it, it appears that the chancellor, besides the illegal demand of fees, had sought to compel candidates for the license to take an oath of obedience to himself-an attempt the success of which would have been fatal to the authority of the university over its members. ${ }^{3}$ The obligation of the oaths already taken was relaxed, and the exaction of such oaths prohibited for the future. The chancellor was also forbidden to exact fines for his own benefit by way of penance for raising excommunications; he was enjoined not to imprison for slight offences and to allow bail in all cases. He was further required to grant a license to all candidates whom a majority of the masters of a superior faculty pronounced qualified, and in the case of the faculty of arts to all candidates approved by six examiners, three of whom were to be named by the faculty and three by the chancellor.

In 1215 these provisions (with some modifications) were embodied in a permanent code of statutes which was imposed upon the

1 Thas in the statute of 1251 against the Daminiasns the theologians dealare, 'Quodsi aliquis contrs dictas eornm ordinationes venire prosampserit, ei societatem suam tam in prircipiis quam aliis penitus denegabnnt' (Balonas, iii. 245). The plead. ings against the ohancellor in 1288 , printed for the first time by $M$. Jourdain (No. aclrxiv.), throw mach light on his ralations with the university. See also the letter of the masters in 1265 (Buløus, iii. 288).

2 See Jourdain, No. Iv.

- Denifle has brought out the fact that one great motive at least of this oath was to prevent the masters licensed by himself from teaching in the territory of $\mathrm{St}$. Geneviève, and so esceping his jurisdiction (i. 684-666). By the brief of 1222 it appears that he had bound the doctors of theology and decrees 'ad regendam inter daos pontes' (Bolmas, iii. 125). 
university by the cardinal legate, Robert de Courçon. ${ }^{1}$ These papal statutes further prescribe the subjects to be taken up for examination. To give an account of the educational system of the university lies beyond the scope of the present article. We are concerned mainly with the growth of the university as an organisation. We riay well, however, pause to notice the enormous importance of these statutes of Courçon in the history of education. For nearly a centary at least Paris had been the educational centre of Europe; for half a century a numerous body of masters had tanght in her schools. But the masters had taught and the pupils had studied the subjects to which their own tastes and inclinations led them. If custom prescribed a certain round of subjects, their area could at least be extended at pleasure, and could expand with every change in the thought and culture of successive generations. The period of study had been limited only by the means and aims in life of the student. Young men, in fact, had studied in Paris as they had studied in ancient Rome, or Alexandria, or Byzantium. Now, a fixed course was prescribed to all aspirants to the more and more coveted honours of the mastership. A minimum number of years was assigned for the attainment of the degree in each faculty -a minimum which in the case of the faculty of arta soon became a maximum. Even the books which the lecturer should teach and the student read were prescribed by papal authority. There had been what are sometimes picturesquely described as university towns in the ancient world, but there had been no sach thing as a curriculum. The idea of a curriculum, so far as Europe is concerned, originates with these statutes of Courçon, unless indeed the legate was only transferring to the domain of liberal education a practice which had already grown up in the Italian law schools of Bologna, in which any examination whatever was necessarily an examination in set books. In that case the whole course of European edncation has been profoundly modified by the circumstance that in Italy the revival of knowledge in the twelfth century took the form of a revived study of the civil law, and that the earliest fully organised universities were composed of law studente. At all events it is indisputable that the set books of modern Oxford and the set subjects of other modern nniversities are a direct inheritance from Courçon's statute of 1215 . Indeed, it is to the thirteenth century that we owe the beginnings of that vast system of competitive examination the application of which in this and other countries to government appointments may be said to constitute not the smallest of the political revolutions of the nineteenth century.

To trace the whole history of the relations between the university and the chancellor would carry us too far away from our subject. By a succession of papal decisions the chancellor long before the end

\footnotetext{
1 Bulæus, iii. 81, 82.
} 
of the century lost his judicial power altogether as well as the power of granting licenses without the advice of the masters. His share in the examination was reduced to a merely formal one. Ultimately, indeed, the examinations by the masters themselves, the severity of which had at one time made a Parisian degree the goal of every scholar's ambition throughout Europe, seem to have been reduced almost to the level of the disputations and exercises of the Oxford schools of a generation or two ago. In 1426 a candidate who achieved the rare distinction of a 'plough' brought an action against the examiners.'

But we must revert to our main subject, the history of the university constitution. The successive stages of the development which we are studying will, however, hardly be intelligible to a reader familiar only with the constitution of modern Oxford and Cambridge without a short anticipatory sketch of the organisation of which we are investigating the origines. The fully developed university was divided into four faculties-the three 'superior' faculties of theology, canon law, and medicine, and the 'inferior' faculty of arts. The faculty of arts was further subdivided into four nations-the French, the Normans, the Picards, and the English. At the head of each superior faculty stood a dean; at the head of each nation a proctor. The rector was primarily the head of the faculty of arts, by whom alone he was elected, but was at the same time the head of the whole university. Each of these seven hodies held meetings or congregations of its own, and, subject to the general authority of the whole university, regulated its own discipline and made statates binding on its own members. The rector presided in congregations of the faculty of arts as well as in 'general congregations' of the whole federation. In the faculty of arts the division was taken by nations; in a 'general congregation' by faculties and nations. After the subject of deliberation had been laid before the assembly by the rector, the several corporations retired to separate parts of the church or convent, and there debated the matter under the presidency of their respective heads. On the reassembling of the university the deans and proctors handed in the corporate votes of the faculties and nations, and the rector 'concladed' in accordance with the decision of the majority of the seven bodies. Only 'regents,' i.e. actually teaching masters, had any right to a seat or vote in congregations. As, however, the oath of obedience to the rector Tas of perpetual obligation, the non-regents were always; bound to obey the rector's summons. At first they were summoned only on rare and extraordinary occasions. In the fourteenth century it became usual to cite non-regents to all important meetings, except for elective purposes; but, when they attended, they roted (so far as

- Bulæus, v. 377. The candidate ascribed his rejection to odiun theologicum. 
appears) with their respective faculties and nations, and never formed-as at Oxford and Cambridge - a separate 'house.' The origin of these celebrated divisions, reproduced (at least in so far as the division into nations is concerned) in all the later imitations of the Parisian constitution, is the main problem connected with the origines of the university. It should be observed that the other great problem, the origin of the rectorship, is intimately bound ap with the question of the origin of the nations. The rector is, in the earliest period, closely connected with the four nations by whose proctors he was elected. He was primarily the head of the four nations ${ }^{1}$ rather than the head of the faculty of arts, though the distinction soon lost all practical significance. This statement forms rather an anticipation of the results of our investigation, but it accounts for our treating of the two problems together.

The solution of these problems has been hitherto impeded by a gross misinterpretation of two important pieces of documentary evidence. In the first place, an episode in the history of Thomas \& Becket's quarrel with Henry II has been, by all the historians of the university before Denifle, relied upon as proving the existence of the 'nations' at that time. Henry offered to submit his quarrel to the arbitration of 'scholars of different provinces, examining the matter with equal scales,' ${ }^{2}$ or (as Becket himself says) of 'Parisian scholars.' 3 It is natural enough that to minds preoccupied with the antiquity of their alina mater the former passage, when interpreted by the latter, should have appeared incontrovertible proof of the existence of the 'nations,' and even of the practice of roting by nations in or about 1164 A.D. But in reality the words imply no more than a proposal to submit the matter to the arbitration of . learnod men from the Parisian schools, chosen from different nationalities to secure impartiality.

With equally little ground an allusion has been found to the rectorship in the celebrated charter granted to the scholars of Paris by Philip Augustus in 1200 A.D. ${ }^{4}$ A brawl between some German students and a tavern-keeper hod led to a riot in which several students were killed, and the provost of Paris had headed the assailants. The king being appealed to by the injured scholars inflicted severe punishment upon the provost, and granted a charter by which it was ordered among other privileges that scholars arrested by the provost's officers should be immediately handed over to the bishop. Then follows a clause which protects from arrest at the hands of secular justice the capitale Parisiensium

1 I had not realised this before reading Denifle (i. 90 ff. and $106 \mathrm{ff}$.)

: 'Schoiaribas diversaram provinciaram \&qua lance negotium examinantibas' (Rodulphus de Diceto, Op. hist. i. 837, ed. Stubbs, 1876). In my interpretation of this passage I have been anticipatg 1 by Denifle.

3 Bulæus, l.c.

- Bulæus, iii. 2, в. 
scholarium. Bulmus and his followers have interpreted these words of the rector, whose office the former (an ex-rector) believed to date from the times of Alcuin and Erigena. Recent writers have strangely understood the capitale ass 'a regent master,' but without offering any explanation of so strange a mode of expression. Even Denifle has here missed, or rather rejected, the true explanation. The word capitale merely means 'chattels,' or property, which, like the persons of the scholars, was protected from sequestration except by process of the ecclesiastical court. It is obvious that the correction of these two blunders involves a rewriting of the whole constitutional history of the university during the first half-century of its existence. As the charter of Philip Augustus has sometimes been treated as a kind of deed of foundation, or at least as the first official recognition of the university, it may be added that the privileges which it bestows are bestowed upon masters or scholars simply as such. There is no official recognition of the university, its officers or members. The conferment of privileges upon masters and scholars no more implies the existence of a university than the exemption of chemists or dissenting ministers from jury

The clanse rans as follows: 'In capitale Parisiensium scholarium pro nullo forefacto justitia nostra manum mittet, sed si visum fuerit illud esse arrestandum per justitiam ecclesiasticam arrestabitar et arrestatum custodietar, ut de illo capitali flat quod per Ecclesiam fuerit legitimè judicatum' (Boullai's text corrected by Denifle, i. 7). I had already conjectured from the meanings in Du Cange that capilate must here mean 'chattels,' when I came npon the Frenoh translation of the provost's oath, in which the provisions of each of the clanses in the charter are given in succession. It runs, 'Vous jurerez qu'en chastel des ecoliers ne ferez mettre main' (Jourdain, p. 66). I may add the following remarks: 1. The ase of capilale either for ' head' or 'regent master' is unexampled. 2. The continued ase of the neuter would be singular. 8. The clanse would be mere surplusage, since masters as well as scholars have been already privileged from arrest. 4. For the use of arrastari of the sequestration of property cf. Jourdain, No. ccclrri., and Bulmas, iii. 469. 5. Provision is mode for the case where the justitia ecclesiastica cannot be found in the case of a scholar, not in the case of the arrest of the capitale. The sequestretion of property could not be so urgent as to require a temporary detention by the secular arm. According to the other interpretations a privilege if conferred on the 'scholar' which is withheld from the reclor or master. Jourdain's own view is that 'hoc verba non rectorem sed aliquem e magistris aperte declarant' (p. 47B, n.), and to this view Denifle, though not without hesitation, subscribes. Jourdain (No. cclxxiv. p. 47) relies upon a passage contained in the pleadings of the university. against the chancellor. A doctor of medicine had upset the water in which he had been steeping his herbs apon the watch in the street below. The offleers entered the house, and after nearly killing him by their violerce carried him off to the king's prison. The university contended that its privileges had been violated by the arrest and imprison. ment: ' quod de quocunque esset scholari non debuisset feri, sicat in privilegio regis continetur,' and becanse 'justitia laycalis in capitale scholarium, quantam ad illam injuriam, manum imposuit, quod tamen per privilegium regale fieri non debuit similiter.' According to Jourdain's interpretation there is hardly any distinction between the two breaches of privilege complained of. It is easy to enppose that the doctor's property had been seized by the guard, even if the forcible entry was not construed as an attachment of property by lay justice. Even if capitale is here understood to mean a master, it must be a misinterpretation. 
service by act of parliament implies the existence of a guild or corporation composed of members of these classes of the community. ${ }^{1}$

The origin of the 'nations' and of the rectorship can hardly be understood without some knowledge of the nature of the universities of a widely different type, of which Bologna is the original. Already in reducing their rude professional customs to written statutes the Parisian masters had probably been influenced by the example of the students of Bologna. The rectorship, the proctorships, and the four 'nations' of Paris are still more unmistakably adaptations to somewhat different circumstances of Bologna institutions.

The universities of students at Bologne originated, it would seem, somewhat later than the Paris university of master's. ${ }^{2}$ In the Italian municipal republics, as in the cities of ancient Greece, the non-possession of civic rights involved serious disabilities. In the absence of any express treaty or agreement the citizen of one city had hardly a locus standi in the courts of another. In such a state of society the position of a body of students in a foreign city would hardly have been tolerable without some special protection. In a society honeycombed with guilds and societies of arms it was inevitable that protection should be sought in the formation of societies of a similar character by students from different countries. The foreign merchants had in several places successfally attempted thus to compensate the loss of their natural citizenship by the creation of an artificial citizenship, by the erection of a ciritas in civitate. ${ }^{3}$ Their example was followed first by the transalpine students, afterwards by those from various parts of Italy. At first the protection secured to its members in their relations with the townspeople. was merely that of association. The students could 'boycott' an offend. ing landlord or tradesman, or, if justice were refused by the magis. trates, threaten to leave the town and ruin its trade. Ultimately, after a long struggle, the city of Bologna, and other cities in which secessions of Bologna students had taken refuge, found it necessary to make terms with the powerful strangers, to recognise the jurisdiction of their rectors in the canses of scholars, sometimes even to compel their own podestids to swear to respect their privileges. Though originally formed for protection against the town and for the settlement of disputes among themselves, the weapons which had proved so effectual against the city government were in time directed with equal success against the professors, who ultimately became the humble servants and employés of the students and their rectors.

1 The same remarks may be made of Frederick I'B authentic Habita of 1158, which SIr. Mullinger erroneously epeaks of as offlially recognising the existence of the university (Cambridge, i. 72). It would not do this even if Bavigny's arbitrary limitation of it to the students of Bologna could be substantiated.

2 Denifle (i. 158-9) places the fonndation of the first nniversity at Bologna at the end of the twelfth century.

- Denifle, i. 186. 
But at first the university of students no more claimed authority in strictly acaciemic affairs than the Oxford Union Society or the student corps in the German universities. The bond of union between the students was as much the fact of their being foreigners as the fact of their being students; and the students of Bolognese birth were not members of them at all.

From the middle of the thirteenth century there were only two universitates at Bologna- one of citramontani, the other of ultramontani -each with its separate rector, while the two societies were closely associated and for practical purposes were little more than subdivisions of the same body. But at the beginning of the centary it has been made abundantly evident by Denifle ${ }^{1}$ that there were four of these societies, as there continued to be till a later time in some of the daughter universities formed by secessions of atudents from Bologna; and these societies were originally quite independent of one another. Each of them was a miniature republic. Its constitution wes an imitation of the constitutions of the earliest merchant guilds or societies of arms, which were themselves reproductions of the municipal constitutions. ${ }^{2}$ The term rector was already in use for the elected chief magistrate of a guild. ${ }^{3}$ The executive consisted of a body of conciliarii, suggested by the town councils, chosen by the several smaller nationes composing the university; while the supreme governing body was, as in the city democracies, the whole body of members. The elaborate methods of indirect election, the checks against hasty alterations in the statates, and numerous other minor constitutional features find close parallels in the constitutions of the Italian cities of the period in which they were introduced.

It is obvious that the four nations of Paris are an imitation of the four Bologna universities. There is no trace whatever of their existence for about the first half-century in the history of the Parisian university of masters. Even the faculties did not exist as subdivisions of the university. The theologians must from an early period have held separate meetings for the celebration of their own inceptions, for disputations, and for the discussion of theological questions submitted to them by the bishop of the diocese or by private individuals; nor would the artists have admitted the theologians to the inceptions of their own facalty. But in the university congregations all masters were equal and voted as individuals. The university was a society of masters of all faculties, not a federation of faculties.4

I Bd. i. 136, 188. The real history of the origin of these Bologna universities has been written for the first time by Denifle.

Denifle, i. 145-6, 149.

- The masters of theology and canon law are associated with the artists in the earliest documents. The doctors of medicine are mentioned as obtaining their 
It was in the conduct of the protracted litigation with the chancellor that the university first experienced the want of the two important attributes of a corporate existence which were still denied it-the election of common officers and the use of a common seal. From two briefs of the years $1219^{\prime}$ and one of $1222^{\prime}$ it is evident that the bishop and chancellor were straining every nerve to suppress the formidable organisation which threatened to destroy the authority of the church of Paris over the masters and scholars who were multiplying beneath her shadow. An old ordinance or proclamation against 'conspiracies' was furbished up, and the university was excommunicated en masse for disobedience to it. To the mind of a canon of Paris the very existence of the university was nothing more or less than a conspiracy - an unlawful secret society formed by a certain class of very inferior clergy for the purpose of resisting their canonical superiors. The language of the briefs ${ }^{3}$ makes it quite plain that the acts of conspiracy were simply the passing of statutes by the masters for the government of themselves and their scholars together with the administration of oaths to observe them. The church of Paris claimed that no such ' constitutions' should be passed without the consent of the bishop, chapter, or chancellor. When the university respectfully inquired whether the prohibition applied to all constitutions or only to unlawful constitutious, they were expressly told that it applied to all constitutions, lawful or unlawful, good or bad.' It is obvious that the very existence of the university was at stake.

The definitive sentence of the holy see upon the points at issue has not come down to us, but there can be no doubt that in the main Honorius III and Gregory IX continued the policy inaugurated by Innocent III of supporting the claims of the new society. During the 'town and gown' riots and consequent dispersion of 1229 the cause of the university was steadily defended by Gregory

licenses from the chancellor in 1213 (Jourdain, No. xv.); bat there is no express allusion to them as a distinct class in the university till 1221 (Bulæus, iii. 240).

' Bulæus, iii. 98 ; Rer. Franc. Script. (ed. Dom Brial), t. xix. p. 679.

2 Rer. Franc. Script. t. rix. p. 724. It appears that Stephen Langton, archbishop of Canterbary, and others had been appointed arbitrators or delegates.

- 'Dilecti filii magistri et scholares Parisienses nobis graviter sunt conquesti, quod venersbilis frater Parisiensis episcopus excommunicationis sententiam ab $P$. bonæ memoriæ, prædecessore suo, et P. Hostiensi episcopo, quondam apostolic sedis legato, latam de conspirationibus et conjarationibus scholarium minime taciendis tam dudam innovans, eos qui, circa stetum scholarium, sine consensa ipsius, vel capitali sed cencellarii Parisiensis, conspirationem, conjurationem, constitutionem, sea aliquam obligationem, juramento fide vel pond vallatam, facere attentarent, pro sum voluntatis arbitrio, simili vinculo innodavit, et ipsorum insuper pedibus laqueos excommunicationis expandens,' \&c. (Rertm Franc. Scriptores, rix. 679).

- Petierant interpretationem . . . . utram videlicet intelligerent generaliter tam de constitutione licita, utili et honesta, quam de illicita, erronea et injasta. Quibas responditur quod intelligerent generaliter de omni licita vel illicita, bona vel mala,' \&c. (Bulıus, iii. 93). 
against the formidable combination of court and citizens, bishop and chapter; and upon the return of the masters a series of papal briefs secured the triumph of the university and the permanent humiliation of the chancellor, whose power was reduced almost entirely to the conferment of the license after examination with the assistance of the masters. The briefs of 1219 and 1222 are of an interlocutory character. It is in these that we find the first traces of the existence of the nations and their officers, as also of a university seal. While the wholesale excommunications are severely condemned and peremptorily forbidden for the future, the use of the seal is in 1222 forbidden pendente lite except in so far as its use was necessary for the conduct of the pending suit; as also the election of officers by the scholars 'according to their nations for the avenging of their injuries.' ' From the previous brief of 1219 it appears that the primary purpose of the election of such officers was the choice of a messenger or legal representative at the court of Rome, the masters having sworn to abide by their decision in this matter ${ }^{2}$ and since the prohibition of the appointment of such officers in 1222 is coupled with a prohibition against the infliction of fines by the university we can hardly doubt that one of the purposes for which these officers had been elected by the nations was the exaction of these fines."

It would appear, then, that the formation of the nations, or at least the election of officers by them, was a step adopted to facilitate the conduct of the litigation against the chancellor. In 1219 the appointment of such officers is spoken of as a temporary and extraordinary expedient. By 1222 these offices seem already to have acquired something of a permanent character. The analogy of the four Bologna rectors as well as the obvious advantage of such an institution would tend insensibly to convert the procuratores, as they

' See the brief of 1219 in Balmus, iii. 93. The immunity of the aniversity as a whole from excommanication without the special license of the holy see is reinforced in 1222 (Rer. Frarc. Script. t. rix. p. 724) and 1227 (Bulmus, t. iii. p. 169). M. Tharot makes the astounding assertion that Honorius III forbade the excommuniantion of 'aucun mombre de l'université sans l'antoriastion du Baint Siège.' (De l'Organisation, dc., dans l'Universite do Paris, 1850, p. 12.)

- Porro, cum ad prosecutionem appellationis predicte foret nuncius ad sedem apostolicam destinandus, et sine collecte universitas non haberet expensas, magistri liberalium artium fide interposita se ac suos discipnlos astrinxerunt ad servandum quod super hoc a suis procuratoribus contingeret ordinsri' (Bulmus, iii. p. 94). From the brief of 1260 (Jourdain, No. corxxiv.), it appears that these procuratores were four in number. We have possibly an earlier trace of the custom of appointing four representatives upon such occasiong in Innocent II's brief of 1210. A master who had been expelled for breach of the statates ' in quatoor vestram juramento interposito compromusit, illorum dictum pro bono pacis se gratum et ratum pariter habiturum' (Buleous, iii. 60). Mr. Mullinger (p. 71) is mrong in saying (after Savigng) that 'the term universitas is first found applied to' Paris in 1215.

- Magistri etiam a magistro vel scholari poenam pecaniariam per tempus non exigent supradictum, neo scholares interim, secundum nationes suss, sibi quenquam prøtlcient ad injurias alciscendas.' (Rer. Franc. Script. t. rix. p. 725.) 
were called, from temporary representatives or delegates into a permanent executive of the society. At the same time a trace of the original character of the institution remained in the short tenure of the offices of rector and proctor, which were at first held for periods of only a month or six weeks and afterwards ${ }^{1}$ for three months. Whether the appointment of national officers was for a time suspended after 1222, in obedience to the interim papal injunction, is not known. We do not hear of them again till 1237, when the institution appears thoroughly established. A papal bull now issued forbids excommunication without the license of the holy see not only of the collective body of masters and scholars but of 'their rector or proctor,' when acting officially on their behalf. It.is possible that the terms ' rector or proctor' may here be alternative titles of the same official ; ${ }^{2}$ and there are other grounds for the conjecture that when first the proctors were appointed they were called indifferently rectors or proctors. ${ }^{3}$ The term proctor would have been used in virtue of the originally temporary and financial character of

1 From 1279 (Buløus, iii. 444).

2 "Ut nallas in universitatem magistrorum vel scholariam, sen rectorem vel procuratorem eorum, ant quenquam alium pro facto vel occasione universitatis,' \&o. Bach is the reading of Jourdain, p. 49 ; Denifle, i. 112, reads 'rectorum' (if it is not a mere misprint), which can hardly be right; 'nniversitag magistrorum vel scholarium seu rectorum ' (sc. ' magistrorum regentium ') would be an anparalleled expression. 'There is mach diffculty as to the tert of the successive 'conservationes' of this privilege in 1246 and 1252 (Bee Jourdain, pp. $11 b$ and 14a; Denifle, pp. 113, 114), and therefore as to the text of the original. If the above reading be sound, ' eorum ' must apply to ' rectorem ' as well as to 'procuratorem,' so that 'rector ' cannot mean simply a 'regent,' as Denifle explains it.

- The main grounds for my conjecture are as follows :

1. William of Bt. Amour, referring to the events of the year 1256, anys that he was not at that time ' prociurator soholarium vel rector de collegio eorum.' Procurator and rector seem here to be alternative titles of the same offlce (Opera, p. 94, Constantia, 1682).

2. At Cambridge the proctors were throughout the middle ages called 'restors or proctors.' The constitution of Cambridge was derived from Oxford, and that of Oxford (with modifications) from Paris (at some time before the appearance of the single rector there), though in the English universities there were only two nations, Australes and Boreales. I cannot conceive whence the title rector could have been introduced into Cambridge unless at one time the Paris proctors had been so called.

3. In an agreement made in 1228 with the town of Veroelli by a secession of stadents from Padua (a colony of Bologna) we find the heads of different nations or universities called at one time by different nations; one is rector, another procurator, another qrovincialis, while at other times all are styled rectores (Savigny, Gaschichte das rimischen Rechts im Mittelalter, Heidelberg, 1815-31, iii. 618-623).

4. Bodlai tells us (iii. 222) that up to 1249 the nation of France 'semper fere dabat omnes nniversitati rectores.' It is tempting to conjecture that the rea meaning of the documents or statements (if any) on which he based the assertion was that at one time there were four rectors or proctors, the senior of whom, like the southern proctor at Oxford, was permanently senior proctor or rector of the whole university, and that the separate rectorahip arose from the jealousy of the other nations at this arrangement.

At all events it is quite clear that the heads of the nations, by whatever title designated, are much earlier than the common rector artistarum. 
the office; the term rector would have been introdnced in accordance with the analogy of the four rectors at Bologna. The first document in which the rector and proctors are clearly distinguished from one another is a statute of the faculty of arts in 1244, which visits offenders with expulsion till 'satisfaction shall have been made to the rector and proctor on behalf of the 'university' (sc. universitcs artistarum) 'to the full and at their pleasure.' In the same year a statute of the whole university orders that scholars who take a house which has been interdicted to scholars by the university are to be expelled after monition by the rector or a servant sent by him, or in like manner by 'the proctors or a messenger sent by them.' 2 It is now clear that the term rector has come to be reserved for the head of the whole body of artists, the term proctor alone being applied to the heads of the nations, while in 1249 we come to an agreement ${ }^{3}$ between the four nations as to the mode in which this new officer-the common head of the four nations-is to be elected, i.e. by the four proctors.

We see, then, that the nation-organisation came into existence at some time between 1219 and 1222, that it was for a time suspended by papal authority, but that by 1297 it had obtained a fully recognised legal existence; while at some time later than 1222, and probably later than 1237 , the common rectorship was instituted by the united nations. Like the formation of statutes, the appointment of the common proctor, and the use of the common seal, the new organisation is clearly connected with the great war against the chancellor. Bat in one respect the step differs from the preceding efforts after corporate autonomy ; they were taken by the university of masters of all faculties, while in the first mention of the nations we find that it is the 'masters of the liberal arts' who are forbidden to elect an officer 'to avenge their injuries.' This circumstance may at first sight seem to negative the theory which I have put forth as to the origin of the proctorships. It is true that the suit against the chancellor was instituted in the name of the whole aniversity, bat the masters of arts formed by far the most numerous body of masters; the masters of the saperior faculties, who were left outside the new organisation, were in fact a mere handful." And it is probable that it was the masters of arts and their pupils who were practically most interested in resisting the oppression of the ecclesiastical authorities. It was not the elderly and dignified doctor of divinity but the young master of arts and his still younger pupils who would be most in danger of incarceration in the chancellor's prison or of heavy pecuniary penances for assanlt or riot, and who would have most need of the assistance of a powerful organisa-

\footnotetext{
1 Balfens, iii. 195.

$2 \mathrm{Ib}$.

Ib. 222 .

4 In 1208 Innocent III limited the theological chairs to eight. In 1289 there were about 120 regent masters of arts (Jourdain, No. cclxxiv. p. 45a).
} 
tion for the 'avenging of injuries.' It is probable, therefore, that the suit at Rome was practically carried on mainly by the faculty of arts and at their expense. The peculiar relation which must at this time have existed between the legal incorporation of masters of all faculties and the more popular and informal nation-organisation which had grown op within it is well illustrated by a papal brief of $1260^{\prime}$ ordering the payment of debts contracted by the society ' thirty years and more before.' The suit is distinctly spoken of as the suit of the whole university; the bond for the repayment of the money was sealed with the umiversity seal; the brief itself is directed to the whole body of masters. But it appears that the money had been borrowed by four proctors whom we can hardly avoid identifying with the proctors of the nations; and the order for the repayment is in a special manner addressed to the rector, though it was not till much later that it became the habitual practice to address official communications to the 'rector, masters, and scholars.' The small proportion which the masters of the superior faculties bore to the whole body, together with the fact that but for the rector the university was still an acephalous corporation, is by itself almost a sufficient explanation of the curious circumstance that the rector of the inferior faculty of arts rapidly became the real head of the whole society. The probable history of the relations between the university and the faculty of arts during this transition period is that, in consequence of its superior numbers, organisation, and activity, the affairs of the university were passing more and more into the hands of the faculty of arts. The doctors of the superior faculties were merely called in to give their assent to what had been already settled upon by the masters of arts. Since the superior faculties had at this time no heads of their orm, the presidency of the rector in such 'general congregations' was inevitable.

It is impossible to fix the exact date at which the practice of voting by faculties and nations came into vogue, but a circumstance in the anti-chancellor movement which has hitherto been passed over helps to explain its origin. In one only of the matters at issue between chancellor and university does the papacy seem to have failed to support its protégé. In 1225 the university seal was solemnly broken by the papal legate ${ }^{2}$ and the formation of another strictly forbidden. Foiled in its efforts to gain this essential attribute of corporate autonomy, the masters seem to have evaded the prohibition by setting up separate seals for the four nations, by the joint use of which the assent of the artists could be signified to the acts either of the faculty or of the whole university. ${ }^{3}$ This

1 Jourdain, No. clrxxiv.

- Possibly as a breach of the interim injunction of 1222.

- The statute of 1244 is sealed with the four seals, while the university seal was not granted till 1246 (Jourdain, No. rciv.; Denifle, i. 78). 
step naturally had a tendency to stereotype the division of the faculty of arts into four nations; the faculty in fact ceased to exist except as a federation of four distinct corporations. Since the seals could not be used withont the consent of the nations to which they belonged,' separate debate and separate roting became necessary whenever a statute or other document had to be sealed. ${ }^{2}$

The exclusion of the superior faculties from the nations made it necessary for the former to complete their separate organisation if they wanted to maintain their influence in the deliberations of the whole body. When the nations adopted the plan of discussing university business in preliminary assemblies of their own under their own chiefs, it was natural that the superior faculties should claim a similar right; thus the practice of voting by faculties and nations in the general congregation was a natural and obvious extension of the principle of voting by nations already established in the faculty of arts. The great quarrel with the Mendicants, by compelling the secular masters of theology to fall back for support upon the powerful and highly organised faculty of arts, did much to bind the faculties together as well as to secure the predominance of the faculty of arts. ${ }^{3}$ At the same time the manner in which the controversy terminated stereotyped the separation of the faculties. The faculty of theology was compelled to admit the Mendicants into its ranks without their taking the oath of obedience to the statutes, while the faculty of arts successfully refused to admit them. The university now contained cle facto members (though, as they had not sworn to the statutes, they may not have been considered de jure members) who were not, and had

1 This is all that is implied by the consensu eorundem, which does not show that the nations were not regarded as integral parts of the facalty, as Denifle contends (i. 80).

2 It is not easy to indicate briefly the differences between my view of the origin of the nations and Denifle's. 1. He holds that the nations were an organisation of scholats, in whioh the masters of arts were included as scholars of the superior faculties (i. 84, 88, 97 ff.); but, as he admits that those below M.A. had no voice in the assemblies (p. 102), and as the university itsalf is constantly spoken of as a body of scholares, the distinction seems to rest on a somewhat alender basis. I admit that the nations were formed for a different purpose from the facalties, though I see no reason to believe that after the nations were once formed any distinction was in practice maintained between the faculty of arts and the collective nations. 2. He holds that the nations were formed for purposes of discipline among the scholars (i. 104). This view seems to me unfounded and enechronistic. I believe that the primary purpose of the organisation was (a) ' ad injarias alciscendas' by legal process and otherwise, $(b)$ to elect officers and to collect and administer funds for this purpose. See also below, p. 673, note 2. In 1251 and earlier we find the English nation prescribing the stadies of candidates for the license or for 'determination.' (MS. in the library of O.C.C., Oxford, No. 883 , tol. $177 \mathrm{seq}$.)

- The close connerion between this conflict and the growth of the importance of the rectorship is indicated by the oath taken with the oath of obedience to the rector. 'Item, stabitis cam magistris secularibus et deffendetis statum, statuta et privilegia eorum,' \&c. (Denifle, i. 124). 
never been, members of the faculty of arts, and with whom as individuals the masters of arts refused to have any consortium whatever. At the same time the bull Quasi lignum vita, issued in $1255,{ }^{1} \mathrm{recog}$ nised and enforced the principle of roting by faculties, since it made a decree for a suspension of lectures binding only if a two-thirds majority in each faculty voted for it. At first it would probably have been impossible to force a new statute upon a dissentient faculty or nation. The principle of deciding by a majority-vote was no doubt of later and very gradual growth.?

A common head was absolutely essential to bind together the seven corporations into which the university was gradually resolving itself, and at the time when the university constitution was growing up the faculty of arts alone had a head who coald possibly become the head of the whole university. The common struggle against the mendicants, in which it was the theologians who were primarily interested, contributed to induce the superior facalties to acquiesce in the ascendency which had been gradually acquired by the artists and their rector; but at the conclusion of that straggle we find indications of a quarrel between the faculty of arts and the superior faculties, who now began to realise that an organisation practically more powerful and compact than the aniversity itself had grown up within it, and that in that organisation they had no place. ${ }^{3}$ We now find them endesvouring to win back their proper place in the university system. This they did by completing the organisation of the several faculties under deans of their own, and claiming for each faculty a position equivalent to that of nations in the general congregations and for their deans a position equivalent to that of the proctors. The headship of the rector might be denied in theory, bat his presidency was too well established to be successfully assailed. The documents enable us to trace with tolerable completeness the twofold process by which on the one hand the faculties grew into corporations as distinct and fully organised as the nations, while on the other the rector of the artists gradually emerged into the recognised head of the whole body.

We have seen how in 1244 the rector is already employed to execute university decrees. In 1260 he is addressed by the pope as rector of the aniversity and required to enforce payment of debts incurred in the name of the whole university. ${ }^{4}$ In $1267^{\circ}$ we find a deed running in the name of the deans of the faculties of canon law and medicine (who now appear for the first time), the rector and the proctors of the nations, 'by the assent and consent

1 Bulmas, iii. 285.

- In 1277 we find a statute passed 'per totam universitatem quatuor facultatibus hoo volentibus' (Bulmas, iii. 482).

Joardain, No. colviii.

- Ib. No. clrariv.

Ib. No. cervi. 
of all the masters regent in Paris in the aforesaid faculties and in arts.' The faculties of law and medicime assent through their deans; the eight masters of theology, having at present no dean, assent as individuals, their names being recited at the end of the deed. The peculiar and undefined relations then existing between the faculty of theology and the nations illustrate the anomalous position from which the members of the other superior faculties hed just emerged. The non-existence of a dean of theology is explained by the fact that the chancellor acted as the head of the faculty in its separate deliberations, while in the university he had no place at all. The peculiar position in which the most important of the superior faculties was thus placed no doubt contributed to facilitate the recognition of the rector of the artists as head of the university. A deanship of theology was ere long created,' but by this time the rector's position was too well established to be successfully assailed.

In the document of 1267 we saw that the rector was still mentioned after the deans, though already styled rector of the university. In $1289^{2}$ we find this precedence reversed, while in or about the same year a step was taken which practically secured the supremacy of the rector of the artists in the whole federation. The taking of an oath to the rector at inception dates from the institution of the office. But the oath was taken only by members of the faculty of arts. At some time before 1289 a clause was inserted in the oath binding the inceptor to obey the rector and the statutes of the faculty, "to whatever state he might come.' 3 As at least the great majority of the secular masters of all faculties, inclading their deans, had taken the degree of master of arts before proceeding in the higher faculties, this ingenious measure effectually secured the supremacy of the rector in the whole university. If in a certain technical sense the rector was still rector of the artists only, the members of the superior faculties were henceforth extraordinary or non-regent members of the faculties of arts. Henceforth the oath of obedience to the rector supplied the necessary connecting link between the superior faculties and the four nations of artists. Since the members of all faculties were botifid to obey his summons, he alone could convoke a general congregation. The oath too supplied the sanction which was wanting to the principle of the submission of the minority corporations to the corporations forming the majority. The rector, after hear-

\footnotetext{
1 The deanship appears well establisbed by 1297 (Jourdain, No. ccerrvii.), and probably existed at least in 1289 (Denifle, i. 128).

Denifle, i. 121.

- "Tempore vite vestre ad quemcanque statum deveneritis' (Denifle, i. 124). It should be added that in 1281 the university solemnly resolved 'quod facta facultatum ... in quantum illa facta respicinnt privilegia universitatis sed negotia, sant facta universitatis' (Buløas, iii. 456 ; of. Jourdain, No. celxix.)
} 
ing the votes of the seven corporations, ' concluded' in favour of the majority; in other words, he commanded the minority to obey the decree, and every member of the university was bound, on pain of perjury, to obey the command. Hence the almost superstitious importance attached to the rectorial ' conclusion,' which was deemed essential to the validity of any resolution of the aniversity.

From this time at least there could be no doubt about the rector's position as virtual head of the whole corporation. As a constitutional technicality it might be maintained, and no doubt was maintained by the sworn enemies of the faculty of arts, the Dominican theologians, that the rector was not the head of the university, as is still maintained with much earnestness by the learned Dominican to whom I have so often had occasion to refer. The fact that the precedence of the rector at ecclesiastical functions was till the middle of the following century disputed by the dean of theology - often, it must be remembered, a bishop or archbishop - proves nothing against his virtual headship. To ordinary minds it would appear that an officer who summons the meetings of a society, ${ }^{1}$ who presides at those meetings, whom every member of the society is bound to obey, and who executes its decrees, is for practical purposes the head of that society. If Prince Albert Victor Edward had been allowed when an undergraduate at Cambridge to walk out of chepel before the master, that would hardly have made him ' head' of Trinity College.'

1 There Fas a dispate as to the made by which the rector should summon the faculties of canon law-about his right to do so there was no dispute-in 1279 (Bulmas, iii. 445). It is true, as Denifle arges (i. 122), that in 1283 (Jourdain, p. 496) the chancellor contends that the faculty of theology was only summoned supplicardo et rogando, bat he does not mention that the contention was not ad. mitted by the faculty of arts.

2 Denifle holds that the rector was not recognised as the head of the faculty of arts till 1274 (pp. 110, 119, 120) or as head of the university till the middle of the fourteenth century. I have not space to examine his arguments in detail, bat the contention rests mainly on the fact that the rector's name is not mentioned in the enacting clause of the statates of the faoulty till 1274, or in those of the aniversity till 1348 (pp. 109, 110). Denifle relies upon the analogy of Oxford and other universities; bat, at a time when there was no doabt as to the chancellor being head of the university of Orford, the statates de. by no means uniformly run in the name of the chancellor and aniversity. He further alleges (p. 121) that the rector cannot have been considered head of the university in 1289 , since the faculty of arts declare in that year that the pope wus head of the university. This is inaccurate. What the faculty says is (Jourdain, No. cclxxiv. p. 492), 'Parigiensis universitas non credit nec confitatur secundum suum rectorcm habere capat aliud a vestra sanctitate.' The words distinctly imply that in a sense the rector was head of the university. What is denied is the headship of the chancellor. As early as 1255 the secolar masters of all faculties speak of 'rectorem universitatis nostra' (Bulsur, iii. 257). It is therefore useless for Denifle to explain that in 1261 'rector aniversitatis' means 'rector universitatis artistarum.' Father Denifle does not oeem to realise that the question whether the rector was head of the university is one which might have been answered in a different way by different persons at the same time. It is certain that the. rector was commonly spoken of as 'rector of the ani- 
If the facts which I have been attempting to summarise appear dry and uninteresting in themselves, they tend to explode many somewhat famous a priori historical theories. They show us that the union of many separate faculties, representing collectively the omne scibile of the age, was originally no part of the essential idea of a university. That it has now become so is due to the fact that later universities were framed on the model of Paris, and that in Paris the necessities of resistance to a common enemy, the chancellor of Notre Dame, drew together the teachers of all branches of knowledge in a single society. The same facts show us that the supremacy of the faculty of arts in the university of Paris was not due to a far-sighted recognition of the principle that liberal education is the primary, professional education only a secondary function of universities, but to a highly peculiar series of incidents in the same great world-important struggle between the Parisian students of the thirteenth century and the cathedral chancellor. It would be difficult, indeed, to exaggerate the historical importance of the series of accidents which combined with the much deeper current of the ideas and tendencies of the age to make the organisation of the university of Paris what it was. The most important feature of that curious federal constitution was the pecaliar relation which subsisted between the faculties of theology and canon law on the one hand and the faculty of arts on the other. The theologians by themselves would never have played the part in the ecclesiastical and political history of Europe which the university of Paris played in the fourteenth and fifteenth centuries. The school of Bologna was as famous as a school of law as that of Paris was as a school of theology. But there is perhaps only one occasion when the Bolognese doctors played a great part in history-at the diet of Roncaglia in 1158, when the 'four doctors' advised Frederick to enforce his regalian rights against the claims of the Lombard cities. And then the doctors acted merely as individuals. The faculties as such never played a great part in history. On the other hand a society of masters of arts could hardly have made its voice heard with authority on questions of theology and ecclesiastical polity. It was the peculiar organisation by which the weight of the first school of theology in Christendom was backed by the powerful democratic organisation of the artists that made it possible for the

versity' at least as early as 1255, and I do not believe that any one bat a friar would have denied the headship of the rector, at least from 1284. The friars occupied an altogether anomalous position in the university, since they were not compelled to take the oath to the statutes till 1318 (Balesus, iv. 181-2).

Denifle's contention that the rector was not head of the faculty of arta till 1274 seoms to be at best a constitutional technicality which could hardly have been understood by a contemporary. There is no real trace of a distinction between the faculty and its collective nations after 1244, and before that we hear nothing for cortain of the rector. 
university to assume the part of an integral factor in the politicoecclesiastical system of Europe. Moreover, it was the same federal constitution which fitted the university for its great róle as the champion of the secular clergy against the Mendicants, and later of the ecclesiastical democracy against the Curia. The theological faculty was divided against itself. It was the support of the great mass of artists, all secular clergy and in intimate relations with the secular clergy throughout France and throughout Europe, which secured the ascendency of the secular theologians und of their ideas in the faculty of theology itself and through that faculty in the Gallican church at large. It was the merely local struggle with the Mendicants in the middle of the thirtecnth century, the struggle of an educational trades-anion against unwelcome and powerfully backed intruders, which sowed the seed of Gallicanism in the great French aniversity, and prepared the way for the development of those democratic though highly sacerdotal ideas of ecclesiastical polity which the influence of the universities, headed by Paris, succeeded for a time, though only for a time, in making part of the theology of the catholic church throughout transalpine Europe.

To insist upon the influence of the university from the time of Aquinas onwards in shaping the theology of the catholic church, and upon its influence in the conciliar epoch in shaping its external history, would lead me too far astray from the subject of this paper. But here the mere accidents of the Parisian constitution played their part in European history. There was a moment when the destinies of Christendom turned in a measure upon the circumstance that at the beginning of the thirteenth century the masters of Paris, to facilitate resistance to their chancellor, imitated the fourfold nation-organisation of Bologna. Those who are familiar with the controversial literature of the conciliar epoch will be aware of the enormous difficulties which prevented the reforming divines from attempting the remedy of a general council till every other means of healing the schism had been attempted in vain. What was feared was the influx of Italian episcopelli in numbers which would drown the votes and voices of the reforming prelates from the northern countries. It is not easy to see how the difficulty could have been got over if the theological prestige of Paris had not to some extent substituted in the mind of northern Christendom a belief in the divine right of doctors of divinity and canon law for the older belief in councils of bishops and abbots; while at the same time the fourfold nation-organisation of Paris suggested a means of voting by which the inequality in the numbers of the different nationalities present could be neutralised. The academic mind had been so familiarised with an organisation which at one time enabled a single German master to outvote a hundred or more Frenchmen that it seemed in no way incredible that the voice of the Holy 
Spirit should speak unerringly through an organ of similar constitution.

Comparing what I said at the beginning of this essay as to the importance of the position which the universities occupied in the life of the middle ages with the details of organisation and strings of dates with which I have been for the most part engaged, the reader may be inclined to complain that I have given him dry bones in place of the intellectual bread which so fascinating a subject seemed to promise. No doubt the history of the rise and progress of the universities presents many aspects more interesting than the one from which I have been contemplating them. The rise of a philosophy and a theology whose very form was determined by the usages of academic disputation, the social life of the universities, their relation to European politics and to religious movements-all these are more interesting topics than such matters as the constitutional position of the chancellor and the growth of the rectorship and the four nations. There are undoubtedly departments of history intrinsically more interesting than constitutional history; but constitutional history supplies the essential framework for the history of social life and the history of ideas. The constitutional history of the universities is the side of their history which has been most neglected, and this article will have served its purpose if it calls attention to the fact that the universities have a constitutional history and that that history is worth studying. ${ }^{1}$

\section{H. RASHDALL.}

1 In qualification of the statement (above, p. 641) that, when father Denifle's work is complete, ' comparatively scanty gleanings will, in all probability, be left for future workers,' dc., I may observe that the unueed materials for Oxford history are very large, and father Denifle's treatment of Oxford in the present volume is very inadequate. The statement, however, is likely to be not much in excess of the truth as to Paris, Bologna, and perhaps the Itrlian aniversities generally. 